\title{
GAMIFICATION AS A NEW TREND IN THE CO-CREATION PROCESS
}

\author{
IVO M. F. M. RODRIGUES ${ }^{1}$ \\ (D) https://orcid.org/0000-0003-2951-485X \\ NUNO F. M. SOARES ${ }^{1}$ \\ (iD) https://orcid.org/0000-0002-1869-0244 \\ JOÃO M. LOPES ${ }^{2}$ \\ (iD) https://orcid.org/0000-0002-2968-4026 \\ JOSÉ C. OLIVEIRA ${ }^{3}$ \\ (D) https://orcid.org/0000-0003-4014-8491 \\ JORGE M. N. G. LOPES \\ (iD) https://orcid.org/0000-0002-2417-0659
}

To cite this paper: Rodrigues, I. M. F. M., Soares, N. F. M., Lopes, J. M., Oliveira, J. C., \& Lopes, J. M. N. G. (2021). Gamification as a new trend in the co-creation process. Revista de Administração Mackenzie, 22(4), 1-33. doi:10.1590/1678-6971/eRAMR210132

Submission: July. 14, 2020. Acceptance: Oct. $1^{\text {st }}, 2020$.

\footnotetext{
European Business School (Isag), Porto, Portugal.

2 Superior Institute Miguel Torga (ISMT), University of Beira Interior (UBI), and Research Unit in Business Sciences (Nucleus of Studies in Business Sciences - Nece), Coimbra, Portugal.

3 University of Minho (Uminho), Braga, Portugal.
}

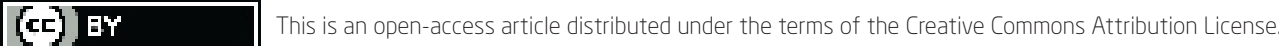

\footnotetext{
This paper may be copied, distributed, displayed, transmitted or adapted for any purpose, even commercially, if provided, in a clear and explicit way, the name of the journal, the edition, the year and the pages on which the paper was originally published, but not suggesting that RAM endorses paper reuse. This licensing term should be made explicit in cases of reuse or distribution to third parties.

Este artigo pode ser copiado, distribuído, exibido, transmitido ou adaptado para qualquer fim, mesmo que comercial, desde que citados, de forma clara e explícita, o nome da revista, a edição, o ano e as páginas nas quais o artigo foi publicado originalmente, mas sem sugerir que a RAM endosse a reutilização do artigo. Esse termo de licenciamento deve ser explicitado para os casos de reutilização ou distribuição para terceiros.
} 


\section{ABSTRACT}

Purpose: Interaction through the use of social media, smartphones, and online games is increasingly growing. Regarding games, it is estimated that part of the population spends more than 12 hours a week in interactions provided by online games. In this context, the objective of the present research is to study and deepen the connection between co-creation and gamification applied to the services sector.

Originality/value: This research aims to contribute to the gap reduction in the existing literature in the areas of gamification and co-creation applied to the services sector. The fact that the research is applied to a peripheral region of Europe and to a different business sector contributes to a better understanding of the relationship established between gamified co-creation and the business sector in these types of regions. It also helps companies in the process of developing and implementing new strategies.

Design/methodology/approach: By using a qualitative methodology, seven interviews were carried out in different companies located in Portugal and operating in the services sector.

Findings: This research will allow a better understanding of the Portuguese business world and if this corporate environment is ready to work with new methodologies. It was possible to point out some good practices related to the implementation of a gamified co-creation methodology, as well as to provide an alert for the negative aspects that may arise when working under this approach. Companies acknowledge that the adoption of a gamified co-creation methodology brings some advantages and increases their competitiveness levels in the market.

\section{KEYWORDS}

Gamification. Co-creation. Companies. Marketing. Peripheral region. 


\section{INTRODUCTION}

For decades, the aim of marketing strategies was focused on the triad, product, price, and promotion. Although they are critical for success determinants, from the 1990s on, the relationship with customers has gained a greater level of relevance ( Kotler, Kartajaya, \& Setiawan, 2016). Current consumers are more informed, demanding, and ready to suggest improvements or even to participate in a co-creation process Kohler, Fueller, Matzler, $\&$ Stieger, 2011). Consequently, under a globalized and highly competitive context, this new trend is an added concern for companies, mainly regarding the products' life cycle and their quality standards (Tekic \& Willoughby, 2017).

Knowing that consumers are getting more demanding, the influence of opinion makers is becoming increasingly narrowed, thus, compelling companies to develop their marketing focused on generations with a high digital propensity (Fuchs, 2014). Therefore, an extra effort is necessary in order to grasp their attention; that is why many brands use gamification strategies to improve their engagement with these audiences (Alexander, 2019).

According to Kotler et al. (2016), the European market is in a period of transaction and adaptation to a digital economy in which the large use of social media allows the comparison between competitors and a quick disclosure of the results of experiences, with unpredictable repercussions, mainly if they are negative (Abdulahi, Samadi, \& Gharleghi, 2014). Brands that are perceived as belonging to the customer tend to distinguish themselves positively from the competition in aspects such as involvement and purchase intention ( Ward, Yang, Romaniuk, \& Beal, 2020); as a consequence, it is necessary to put in practice a set of methodologies to help companies in the development of their products to assure that they will meet the expectations of their clients, allowing them to feel that products were created by them and for them (Singh \& Sonnenburg, 2012).

Hamari, Koivisto, and Sarsa (2014) reiterate that gamification positively affects consumption loyalty, motivation, and engagement. However, only a few studies addressing the topic of brand context are available. For this reason, it is important to analyze the consumers' motivations in the involvement with the gamification experiences, as well as their impact on the consumer's commitment to the co-creation and brand experience process (Nobre \& Ferreira, 2017). Nobre and Ferreira (2017) explore the motivations that lead to the implementation of gamification systems with a clear effect on co-creation and brand value. The authors suggest other qualitative researches using focus groups. 
Gamification offers a considerable return in the co-creation of new solutions, fostering this practice in a collaborative, engaged, creative, and open environment (Ind \& Coates, 2013; Patricio, Moreira, Zurlo, \& Melazzini, 2020). Gamification provides the rules, as well as the essential processes to involve teams and create high-quality solutions ( Sanders, Brandt, \& Binder, 2010). The research of the connection between gamification and co-creation allows the development and understanding of how co-creation practices can be improved (Patricio et al., 2020).

Nowadays, we witness attempts by several companies to make co-creation more pleasant and user-friendly. However, the link between co-creation and gamification is still not observable in the majority of scientific articles (Patricio et al., 2020). If we deepen the literature search within the services sector, the results are even scarcer ( Oertzen, Odekerken-Schröder, \& Mager, 2020). Consequently, the objective of the present research is to deepen the connection between co-creation and gamification when applied to the services sector, testing the level of acceptance of this methodology in service companies involving a business sector located in a peripheral country. Also, it is sought to aid companies in the process of developing and implementing new strategies in the same manner.

This research was carried out following a qualitative perspective through the organization of interviews with company managers who perform functions related to the area of marketing across Portugal. The present research was applied to seven different companies operating in the services area in order to allow a comparison between companies within the same sector.

After this introductory text that presents the framework related to the topic in question, as well as the clarification associated with the source and motivations that have led to the present research, the second part addresses the literature review on the subject and the main concepts. The third part describes the methodology used. Next, the results are pointed out, which are discussed by comparing the data obtained. Finally, the conclusion is presented, reflecting on the main findings of the research, its practical implications, limitations, and future lines of research.

\section{CONCEPTUAL FRAMEWORK: CO-CREATION AND GAMIFICATION}

The tertiary sector (services) is the sector in which we can observe the highest level of competition amongst organizations; therefore, the number 
of companies that use clients to increase the level of participation and engagement has increased. However, the information available to prove the success of co-creation applied to small and medium-sized companies is scarce ( Omar, Kassim, Shah, Alam, \& Wel, 2020). The same can be said about gamification, which has been frequently used in large companies in order to captivate the external and internal public through formal processes. Nevertheless, not much is known about the success of this methodology when used by small and medium companies, as they tend to work with informal processes (Woźniak, 2017).

The topics of gamification and co-creation are relatively recent in business environments. Some authors state that gamification began to be used by organizations from 2005 onwards (Zichermann \& Linder, 2010); as far as co-creation is concerned, it is a common belief that its proliferation began in 2004, after the publication of the book The future of competition: Co-creating unique value with customers, by Coimbatore Krishna Prahalad and Venkat Ramaswamy (2004b).

Although these topics are in the very beginning, they are not connected with several co-creation strategies applied over the time when gamification acted as a process, an enabling tool, and a methodology that has become visible in a wide range of business areas ( Charitsis, Yngfalk, \& Skalen, 2019; Harwood \& Garry, 2015). Hereinafter, we will summarize these two topics, addressing their crucial aspects, allowing a better understanding.

\subsection{Co-creation}

The co-creation topic has frequently been surfacing in contemporary society but still lacks some clarity regarding its precise definition (Vedrashko, 2011). Despite this, there seems to be some unanimity regarding the implications of this approach, which derived from the new social patterns that have represented the transfer of power from companies to their connected consumers (Kotler et al., 2016). In this context, co-creation is always related to the interactions between the company and the final client (Prahalad \& Ramaswamy, 2004a). Considering this, the definition of company co-creation value by the clients emerged in the 1990s (Kambil, Friesen, \& Sundaram, 1999). However, it has gained an increased reputation with Prahalad and Ramaswamy (2004b). Co-creation is presented as a management initiative, which occurs when an external element - individual or collective - is associated with the business, thus, contributing with added value, content or marketing, and an active and direct role aiming to improve business production 
and profitability. The goal of this strategy is to understand what the consumer is looking for and adapt the business in consonance with the wishes and needs of the market, thus, offering the most adequate product with increased success possibilities (Prahalad \& Ramaswamy, 2004b; Zwass, 2010).

Brands did not become the consumers' or stakeholders' mind readers. However, the most successful companies started to be fully informed about what they were looking for, and the value obtained by a product or service, as long as knowledge was shared, and the experiences became the focus of any creation. Traditionally, the value creation process is made underlying the markets, unilaterally driven from the producer to the consumer, together with differentiated perceptions and rules between the officials involved in the production and consumption actions (Prahalad \& Ramaswamy, 2004b; Ramaswamy \& Gouillart, 2010). Considering the need to provide a sustainable answer to the highly competitive and totally globalized markets, it became a key factor for organizations and managers to understand that longterm added value is crucial (Aaker \& Joachimsthaler, 1999).

Consumers exposed to better and updated information become more active and connected. They look for satisfaction through experience, thus, disrupting the vision associated with the product value (Prahalad \& Ramaswamy, 2004a).

Together with companies and through transparent processes, consumers started to co-create value. Companies abandon the practical internal decision of value creation and initiate the delivery of services and resources in exchange for innovation, creativity, and co-creation, increasing the level of involvement between both. This process is called service-to-service (Witell, Kristensson, Gustafsson, \& Löfgren, 2011).

Researches and literature reviews on co-creation allow a better understanding of this relationship's construction process, which is also a transfer of creation and decision power. Prahalad and Ramaswamy (2001, 2004b) paved the way through the proposal of the DART model (Figure 2.1.1), which is composed of basic elements necessary to assure co-creation, more specifically: 1. dialogue, 2 . access, 3 . risk/benefit, and 4. transparency. These basic elements allow managers to define starting points towards a co-creation strategy, capable of initiating a relationship using any of the interaction means between the company and the stakeholders (Taghizadeh, Jayaraman, Ismail, \& Rahman, 2016). 


\section{(Figure 2.1.1) \\ DART MODEL OF VALUE CO-CREATION}

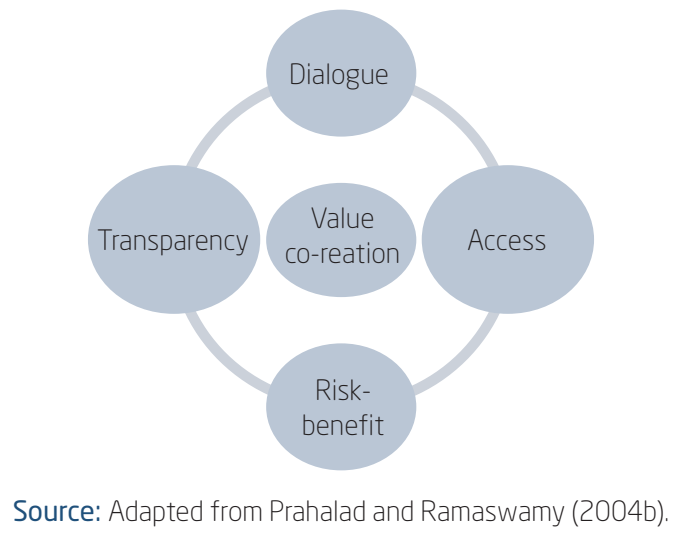

Apart from the DART reference model for co-creation, other authors map the companies' and clients' processes and the common grounds between both. They enhance the importance of the relationship between the organization and the client as a group of experiences and lasting, dynamic, and interactive activities. This connection is influenced by emotional (personality characteristics, mood, and feelings), cognitive (developed through information which is present in our memories), and behavioral (actions that result from experiences) factors ( Payne, Storbacka, \& Frow, 2008).

The main process for co-creation is the interaction with the consumer. Obtaining feedback, research, tests, suggestions, and opinions from the clients is the best way to achieve a more accurate result regarding what the target audience is looking for, thus, becoming more loyal to the brand (Martinez-Canas, Ruiz-Palomino, Linuesa-Langreo, \& Blazquez-Resino, 2016).

There are companies that successfully applied co-creation. Lego, for example, was one of the known brands to begin a co-creation project with the fans by gathering ideas through the website for a series of games, as was the case of the successful television series The big bang theory. Ikea was another company with a competitive advantage, which adopted a co-creative approach and, like Lego, launched several products in the market created in cooperation with several designers (Fagerstrom, Bendheim, Sigurdsson, Foxall, \& Pawar, 2020).

Adidas has been maintaining a close relationship with its clients. They have a wide range of collections developed in co-creation, thus, building an innovative e-commerce model in a more customized manner. Therefore, trust serves as a support for the relationship experience with the clients. By 
providing their emotions, knowledge, and behaviors, consumers became active members of a trustful network (Siguaw, Gassenheimer, \& Hunter, 2014). The co-creation process with the suppliers is mainly focused on the optimization capacity of products and services, rendering them into a more efficient and cost-reduced offer. Digital marketing is one of the company's sectors that can most benefit from the co-creation process, as it can be decisive to identify which actions, campaigns, or communication channels will be able to assure a better return and at the same time create a closer relationship with the client (Kuula, Haapasalo, \& Tolonen, 2018).

\subsection{Gamification}

Gamification is a concept that has been attracting a lot of attention from both academics and practitioners, extending its influence amongst a wide range of businesses and entrepreneurial contexts ( Buckley, Noonan, Geary, Mackessy, \& Nagle, 2019). This term is connected with the technological advances felt in the 1980s and the 1990s, which originated a new generation. The so-called Y generation portrays those who are technology fans. However, it was in 2010 that a greater interest arose regarding gamification, which started to be studied both academically and professionally.

Nowadays, the use of digital tools is a reality in the daily life of a substantial share of the world's population, not only in their social life but also at work. These individuals interact through the use of social media, smartphones, and online games, amongst other technological devices. As far as games are concerned, it is estimated that part of the population may spend more than 12 hours each week in interactions provided by online games (Yust, 2014; Zichermann \& Linder, 2010). In this context, the concept of gamification is being discussed by several authors, and its definition changes according to the approach made by different authors (Gatautis, Vitkauskaite, Gadeikiene, \& Piligrimiene, 2016).

However, independently from the wide variety of usable applications, there is one which seems to be widely disclosed to explain the gamification concept: "The use of game design elements in non-game contexts" (Deterding, Sicart, Nacke, O’Hara, \& Dixon, 2011, p. 1). Some authors are clearly concerned with the misconceptions that may arise from the incorrect use of the term, considering that it is important to differentiate "legitimate" gamification from "rhetorical" gamification due to the fact that the latter is only an artificial device that doesn't correspond to the original intents of gamification, thus, preventing the liberation of the term's full potential inside the companies (Landers, 2019). 
Considering the varied tools used in the creation of games, in the development of this research, we emphasize three elements that are frequently pointed out as being essential in the implementation of a gaming strategy: 1. points, badges, and leader boards (PBL) triad, 2. segmentation of the players, and 3. motivation.

The PBL triad helps to define the way we intend to interact with the player and attract him. This triad is composed of three feedback stages: points, badges, and rankings. Regarding the first stage (points), this is a feedback mechanism shared by the players and the creators, and it is usually used to encourage players to foster competition inside and outside the game environment. They are also a precious piece of information for creators due to the fact that they allow the identification of the products that are mostly pursued by players and how they exchange their points, a type of information which can be later translated into reports that mirror consumers' preferences (Werbach, 2014). As far as the second feedback stage is concerned (badges), it consists of the attribution of badges when the player reaches some kind of deed or milestone (Salcu \& Acatrinei, 2013). Finally, the rankings are connected with the acknowledgment of the player's dedication and aim to inspire other players to reach specific stages by fostering their relationship with the game. The ranking should be as transparent as possible, thus, allowing the other players to understand how a certain player has reached a particular position in the ranking (Kim, 2018).

Regarding the second element (players segmentation), for the implementation of a player's strategy, Bartle (1996) establishes the players' segmentation in four differentiated types: explorers, achievers, socializers, killers. The explorer is a type of player who attempts to explore the entire map, trying to obtain the highest possible number of elements in order to show them to the gaming community. The achievers only want to win. Maintaining these players interested is always a challenge, considering the difficulty of creating games where everybody can win. The socializers participate in the games mainly because of their social dimension, although they also want to participate and win. Nevertheless, their motivation is a result of the socialization process. The killers have a more aggressive drive, these players are similar to the achievers; nevertheless, their major difference is related to the fact that winning is not enough. For these players, if there's a winner, then there is also a loser. One of the main motivations is to show off their victory to the gaming community. The segmentation provides knowledge regarding the types of players that the initiative wants to influence. This tool is essential to the definition of the narrative associated with the game. 
Concerning the third element, motivation, the implementation of the strategy by the players can derive from numerous levels and aspects related to survival issues up to the attainment of some source of reward. When relating motivation with gamification, one has to consider the intrinsic motivation theory (RAMP). This theory, presented by Marczewski (2018), links two different studies: "Intrinsic and extrinsic motivations: Classic definitions and new directions", by Ryan and Deci (2000), and Drive: The surprising truth about what motivates us, by Pink (2011). It mentions the four aspects that contribute the most to keep the interest of the player alive: 1. relatedness, 2. autonomy, 3. mastery, and 4. purpose. Regarding relatedness, it corresponds to the wish of being connected to others or to a brand. This may be observed through interactions developed on the leader boards when a specific logo is shown and/or there's an exchange of messages with the other players.

As far as autonomy is concerned, it consists of the need to experience independence and freedom. The perception that people have regarding "autonomy" may vary according to the number of interesting choices/ actions; this can be perceived in the 80/20 rule used by Google for the motivational management of their collaborators. The third aspect that most contributes to keeping a player interested in the game is mastery. Mastery is the desire felt by the player in order to learn new skills and become an expert. This is mainly presented in videogames, it implies the changing of the paradigm, instead of disclosing an instruction's manual, it creates introductory levels with the purpose of teaching the players through experience (on boarding). The last aspect is the purpose, which consists of the sensation of being a part of something bigger than the player (Šlibar, Vukovac, Lovrenčić, Šestak, \& Andročec, 2018).

In conclusion, for the development of a gamification tool, independently of its purpose, the creators should, at least, be aware of the three pillars above mentioned (the PBL triad, the segmentation of the players, and the motivation). These have been established as crucial elements of gamification. Being so, this knowledge is usually a clear indicator of the preparation level of organizations and professionals to implement gamification strategies in their businesses.

\section{METHODOLOGY}

The present research is the result of a methodological approach of a qualitative nature, considering that the main purpose is to evaluate the structural conditions necessary to implement a business strategy. Another 
aim is to observe possible consequences, deviations, and patterns resulting from its implementation, considering that, in these cases, the selected approach is truly crucial due to the fact that it presents a dynamic structure that can be adapted to the respondent's own reality; therefore, it will be fairly easy to explain the "how" and the "why" of the phenomenon under investigation (Lucas, 2014; Minikel-Lacocque, 2019).-

A case study guarantees its own "argumentation" in a particular reality, thus, allowing a better understanding of the facts. It also allows to deepen its operations, therefore, reflecting an alternative research methodology that has been increasingly applied by academics ( Barratt, Choi, \& Li, 2011; (Barratt, Choi, \& Li, 2011; Lopes, Farinha, Ferreira, \& Ferreira, 2018; Yin, 2015). After interview selection (Scharp \& Sanders, 2019), participants were chosen due to their experience in the field and also because they would be able to provide relevant information. Not only about the seven companies under analysis, but also regarding the sector they operate (Services). Respondents were geographically located in the Northern Region of Portugal; nonetheless, they operate countrywide. The individuals were contacted using an intimate and customized approach, aiming to obtain richer and honest answers, thus, trying to lower the influence of the interviewer and to foster the feasibility of the data collected (López-Herrera \& Salas-Harms, 2009).

The above-mentioned interviews intended to analyze the level of knowledge on these topics; perception about their validity, possible market applications, as well as the degree of preparation of those companies to initiate these types of strategies. In order to obtain results to be compared, the script with semi-structured questions applied to companies was elaborated adapting the model previously used in interviews by Nogueira-Pellizzoni and Baldanza (2019), Camargo, Loureiro, and Sodré (2018), and Gomes (2014). The semi-structured questionnaire with open questions was subjected to prior validation before the interviews. The main purpose of the qualitative component was gathering the inputs to further allow the analysis of the data in a more sustainable manner. This previous qualitative collection also allowed access to the information in a more exhaustive way, which was pivotal to explain and contextualize the results that will be presented later.

\subsection{Research questions and method}

The script of the interviews consisted of 24 questions, divided into two segments: the first one aimed to collect information interconnected with the co-creation topic, while the second was related to the gamification theme. The questions were grouped according to their objective, as stated in Figure 3.1.1. 

(A) - The purpose is to identify characteristics of the company and the sector.
(B) - The purpose is to access the level of knowledge on the topic.
(C) - The purpose is to highlight practical applications of the platform.
(D) - The purpose is to collect the opinion of the organizations as far as the application of the topic is concerned.

(Figure 3.1.1)

CLUSTER OF THE APPLIED QUESTIONS

\begin{tabular}{ll}
\multicolumn{1}{c}{ Type } & \multicolumn{1}{c}{ Question } \\
\hline A (Business sector) & $3 ; 7 ; 10 ; 11 ; 12 ; 13 ; 14 ; 23$ \\
\hline$B$ (Knowledge) & $1 ; 2 ; 15 ; 16 ; 20$ \\
\hline$C$ (Applicability) & $5 ; 6 ; 17 ; 19$ \\
\hline$D$ (Opinion) & $4 ; 8 ; 9 ; 18 ; 21 ; 22 ; 24$ \\
\hline
\end{tabular}

The interviews were performed between November 2019 and September 2020 , onsite and remotely, according to the availability of the companies selected. After its conclusion, the data was gathered and filtered. In order to remove possible inconsistencies at this stage, we have contacted the respondents one more time, asking them to provide further details on doubtful replies. All the gathered information is summarized in Figure 3.1.2. 


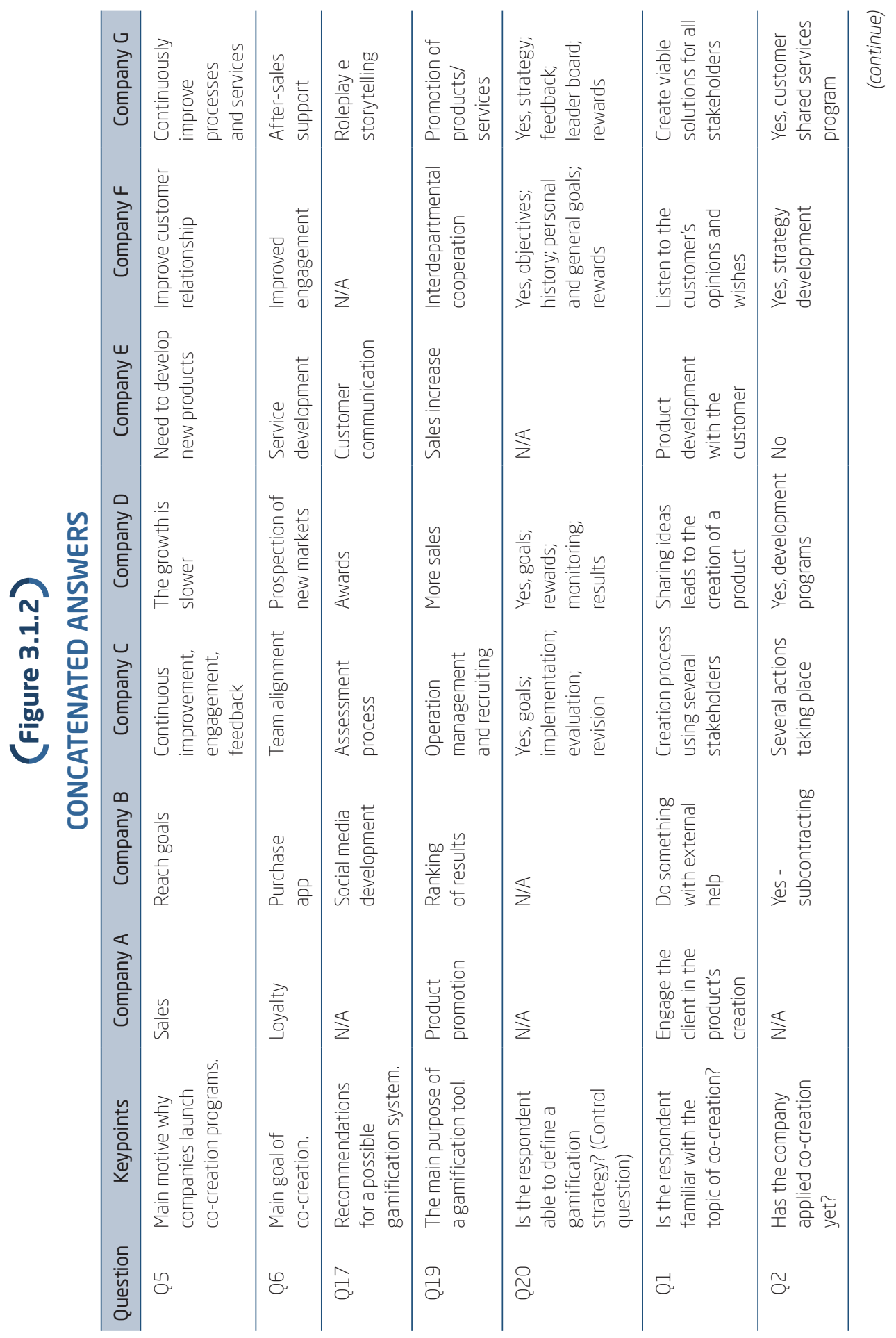




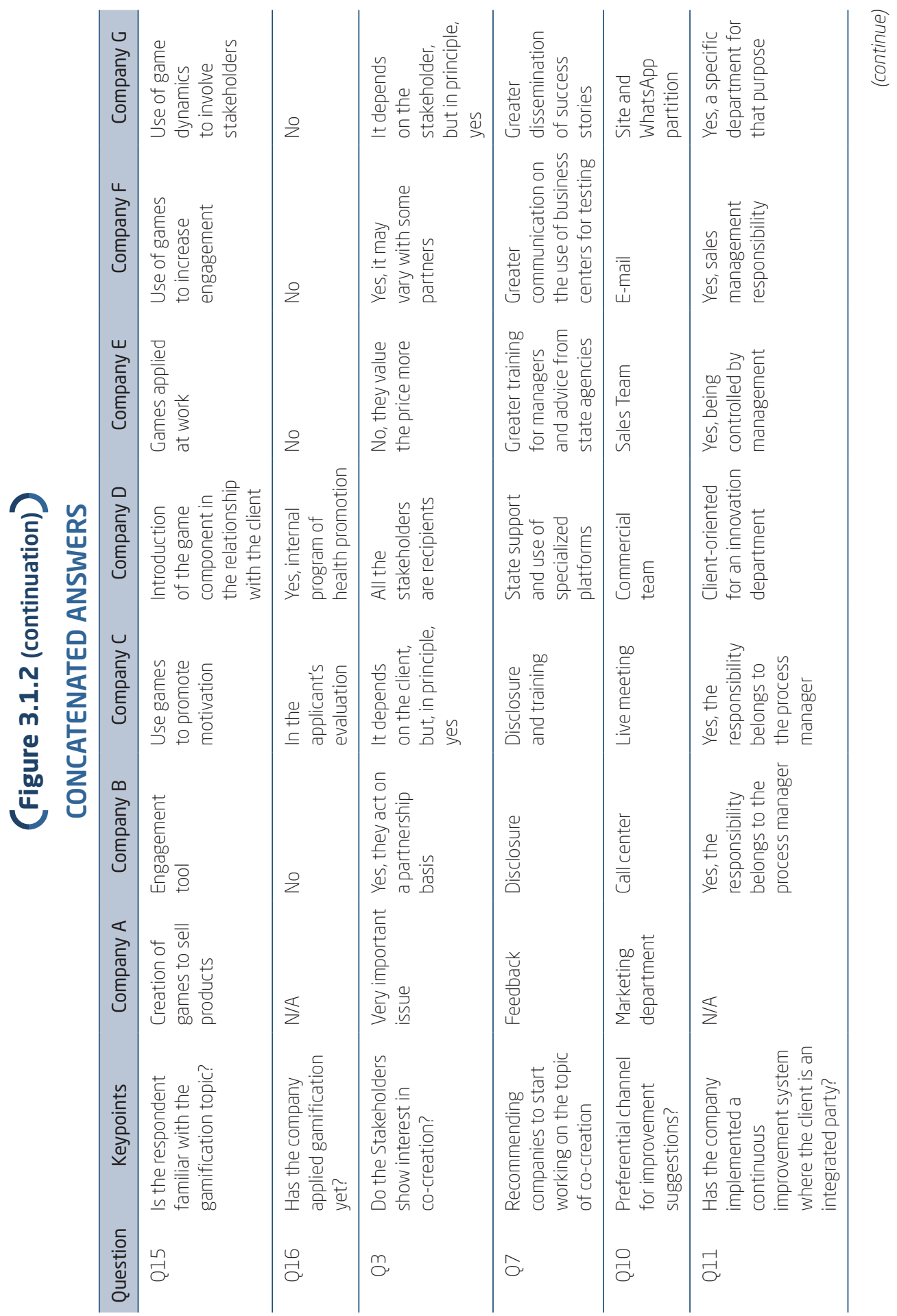




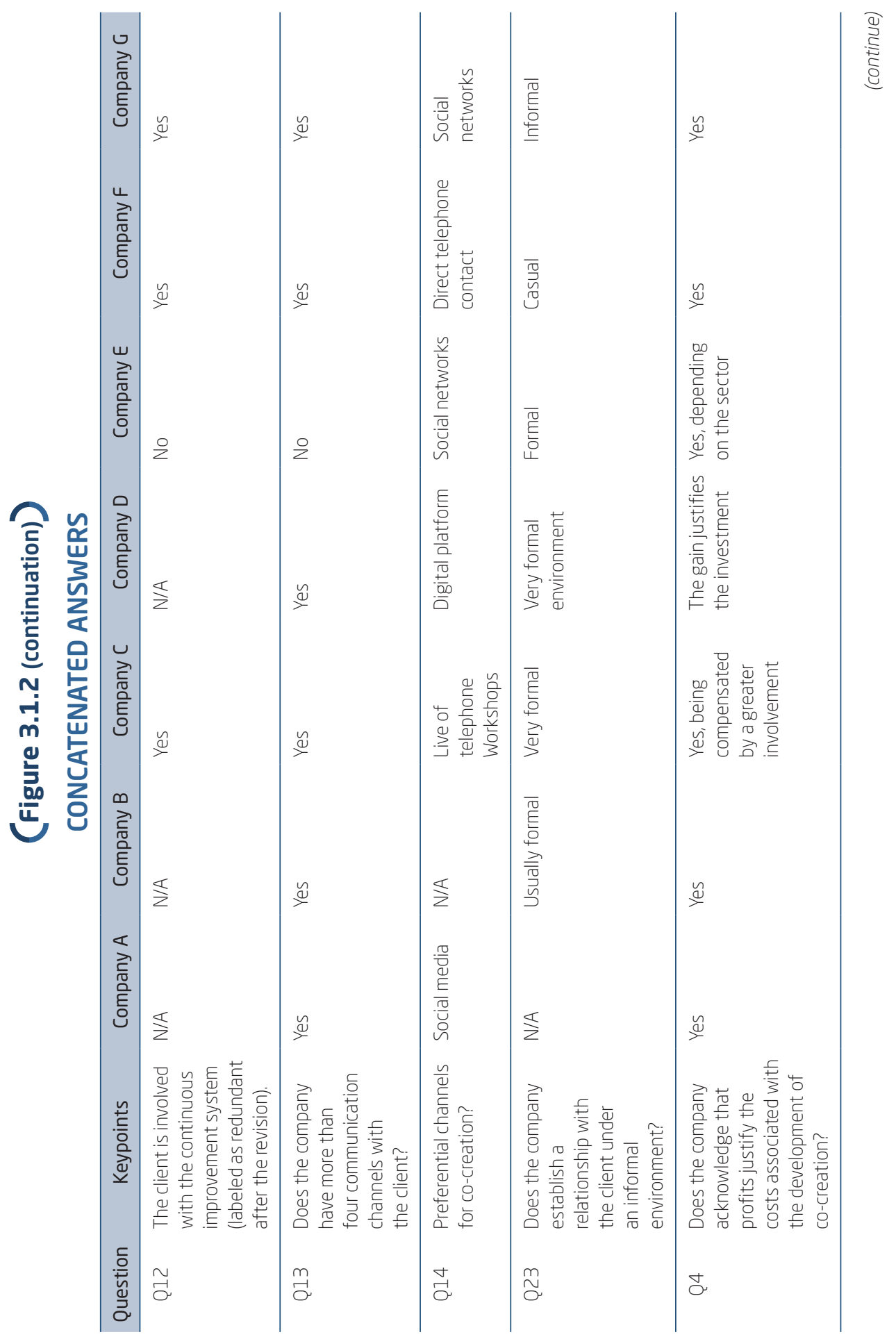




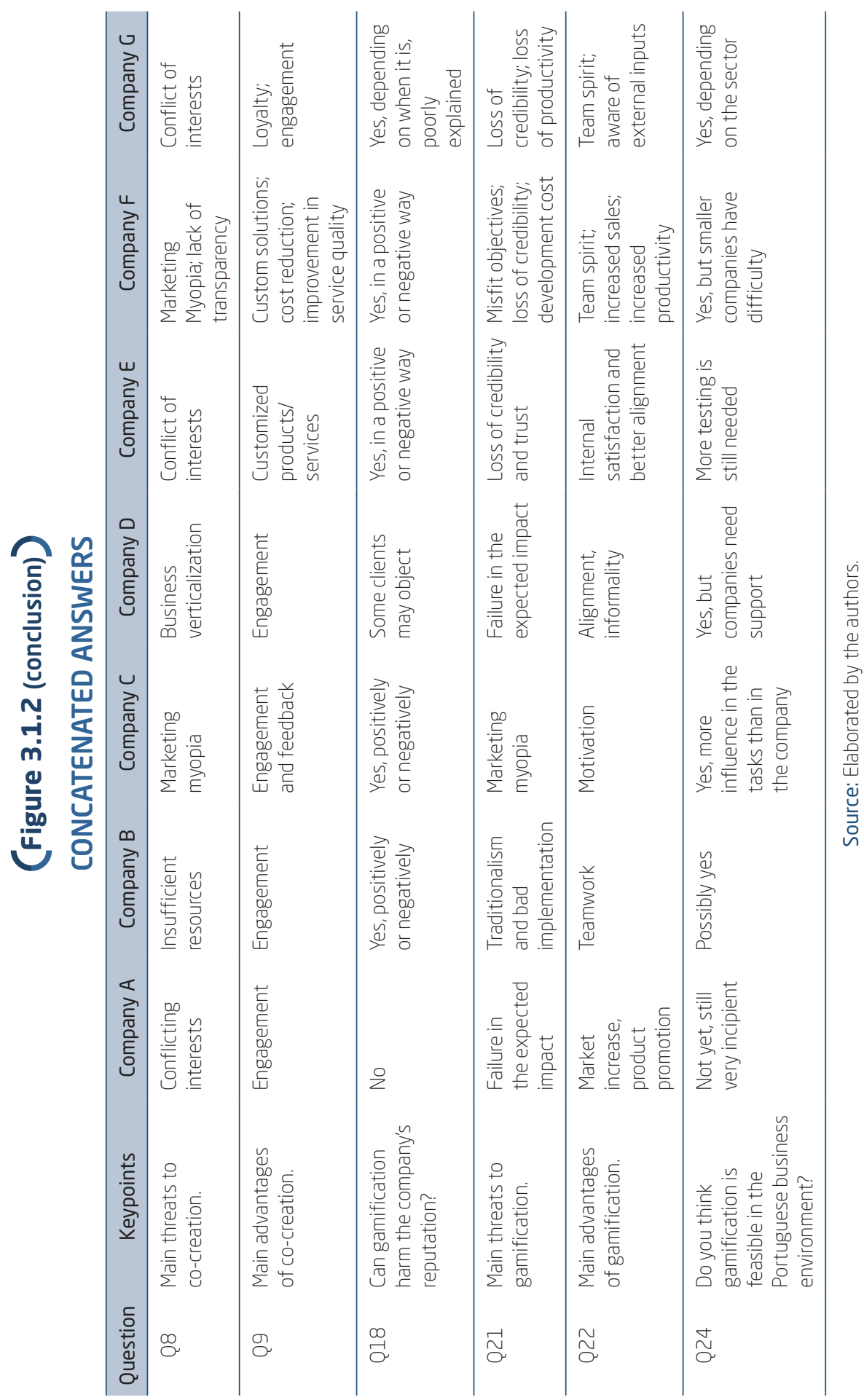




\section{DISCUSSION OF RESULTS}

In Portugal, we can observe a business sector with divergent particularities towards the rest of Europe, where more than $70 \%$ of the companies are family and responsible for $65 \%$ of the Portuguese Gross domestic product (GDP) (Portuguese Family Business Association, 2020). Through the information provided in Figure 4.1, we can see that, in Portugal, $69.2 \%$ of the business sector is allocated in the tertiary sector (services). Therefore, we can conclude that this kind of companies is of crucial importance to the country; however, and as a rule, the culture associated with this type of business sector is highly conservative, which may represent a barrier to the adoption of new commercial strategies such as the case of gamified co-creation (Fernandes \& Ussman, 2013).

(Figure 4.1)

PORTUGAL KEY INDICATORS

\begin{tabular}{lcccc}
\hline \multicolumn{1}{c}{ Indicators } & 1991 & 2001 & 2011 & 2018 \\
\hline Resident population & $9,960.20$ & $10,362.70$ & $10,557.60$ & $10,283.80$ \\
\hline Active population & $5,101.60$ & $5,342.40$ & $5,428.30$ & $5,232.60$ \\
\hline Personnel employed in companies & $2,514.26$ & $3,116.35$ & $3,741.63$ & $4,154.18$ \\
\hline Employed population in the primary sector (\%) & 17.5 & 12.9 & 10.2 & 6 \\
\hline Employed population in the secondary sector (\%) & 33.5 & 33.8 & 26.9 & 24.8 \\
\hline Employed population in the tertiary sector (\%) & 49 & 53.3 & 62.9 & 69.2 \\
\hline Employees (\%) & 69.6 & 72.5 & 78.5 & 83.4 \\
\hline Self-employed (\%) & 26.7 & 24.7 & 20.9 & 16.2 \\
\hline Unemployment rate (\%) & 4.1 & 4 & 12.7 & 7 \\
\hline GDP & $13,646(\mathrm{~B} €)$ & $18,074(\mathrm{~B} €)$ & $18,743(\mathrm{~B} €)$ & $19,871(\mathrm{~B} €)$ \\
\hline
\end{tabular}

Source: Data retrieved from: https://www.pordata.pt/. Accessed in: Sept. 20, 2020.

When analyzing the information in Figure 4.1 in a chronological manner, we can see that the trend felt in the business sector is the migration of companies operating in the primary and secondary sectors to the tertiary sector. In the same figure, it is possible to observe an increase in the number of employees and a reduction in the level of self-employed workers, which may be related not only to the growth of the companies installed in the country but 
also to greater risk and a lack of interest in the creation of new owned businesses. Finally, when crossing the data in the figure above with the last activity report of the Portuguese Association of Family Businesses, we confirm that family businesses are responsible for a significant part of the Portuguese GDP (12.916 billion euros).

The interviews held in the seven companies provided 168 answers. The results obtained were able to ascertain the responsiveness of each one of the companies, as well as to mirror the advantages and disadvantages of applying gamified co-creation in the Portuguese business environment.

After dividing the results by the type of question applied, we started by reporting those related to the knowledge demonstrated by the companies. In this field, and relying on Q1 and Q15, we conclude that, in general, all the companies demonstrated that they are already familiar with the areas of co-creation and gamification and are able to describe the basic processes inherent to each one of the methodologies. Results confirm that companies "C", "D", and "G" are the best prepared since they have obtained the highest rating in this regard; this result is justified by Q2 and Q16, in which it becomes clear that both were already using co-creation and gamification tools and also incorporated those tools in their daily working practices. Even so, in the case of company "G", we see greater use of co-creation to the detriment of gamification.

This result was acknowledged in case studies previously presented in the pharmaceutical industry in Portugal, which intended to relate the implementation of gamification to monitor the different processes of quality revision of the products in a highly regulated and entangled sector, as is the case of the Health sector (Pestana, 2019). This research correlates gamification concepts with the applicability of new organizational processes applied in a case study with the project team of Altran Portugal S. A. Still in the same environment, i.e., human resources companies performing in the national market, through a partnership with the Project Foundry, Randstad Portugal has been developing several projects and solutions using gamification to engage the human resources and motivate teams in its business model. Gamification as a recruiting tool in human resources companies is a widely developed process in which several recruiting scenarios are outlined through the use of gamification experiences, thus, justifying a familiarity with the final results (Zielinski, 2015).

Taking into account that both sectors have shown some knowledge about the above-mentioned methodologies, we used Q5 and Q6 to conclude that five of the seven companies confirmed that co-creation is a type of functio- 
nality directly related to the sales increase. The same happens when the topic gamification is addressed (Q19): although different terms are used, the purpose is still geared towards the increase in sales performance; in the case of company " $F$ ", the objective is oriented towards interdepartmental cooperation within the company. It became clear that one of the main assumptions for co-creation is the creation of value. This means that the answers are connected strictly with a business perspective (internal) tailored to the creation of value represented by money. Such is related to the controversial role of co-creation when the innovators are searching for profits (Martovoy \& Santos, 2012). The wideness of the questions presented allows the evaluation of the level of intention regarding the relational deepening with the client, which, ultimately, aims at increasing the sales (Bai, 2018).

Still related to the topic of applicability, with the exception of companies "A" and " $F$ ", the respondents presented several development lines to co-create gamification methodologies (Q17), of which we can mention "social media development", that is connection promotion with the clients; role play and storytelling, in order to engage the customer with the company; "assessment processes", favoring the individual's evaluation inside the organizations; and, finally, the "awards programs", thus, allowing an alignment of human resources with the institutional goals.

In the present research, we also assessed the environment where the companies are immersed and the way they relate to it. Considering Q3 and with the exception of company "E", which believes that customers value the price more, we concluded that all companies are well aware that their stakeholders highly acknowledge a significant value in the application of co-creation and gamification methodologies. In this sense, and with the exception of company "A", all the respondents involve their clients in the continuous improvement processes. Nevertheless, this usually happens in a controlled and limited environment; even so, companies " $D$ " and " $G$ " have a specific department for this purpose, as stated in Q11.

Etgar (2008) departs from this level of involvement and control, intended to differentiate the process of co-creation from the process of co-production, considering that, in the first case, there is an active participation of the clients in distinct productive activities, whereas, in co-production, the participation of the client is identified in the production stage of the product or service, but limited to the chain integration level, as we could conclude from the answers. The continuous improvement process, in accordance with the clients' expectations, implies listening to the consumers, gathering and disclosing feedback about the whole creation process (Greenwood, 1992), and being 
the main focus of value. From this, the client should be included in new co-creation structures, thus, assuring the expected return (Heavey, Ledwith, \& Murphy, 2014).

With the exception of companies "F" and G", a common characteristic of the Portuguese business environment is related to the fact that companies tend to prefer a more formal communication flow with their clients (Q23). Although most of them provide multiple communication channels to clients, company "F" only provides two channels (Q13), and the majority end up choosing the most traditional tools, such as call centers and sales representatives. This tendency is contradicted by company "G", which bets on a more informal communication through a direct line created in the application WhatsApp (Q10).

Being aware of the above-mentioned characteristics, companies believe that the channels currently preferred by the clients are not the most efficient ones for the implementation of a co-created gamification strategy. Using Q14, alternative channels are presented, such as "digital platforms" for their interaction qualities, "social media" due to their disclosure capacity, and "telephone or live workshops", which are focused on improving the involvement with the stakeholders.

Prahalad and Ramaswamy (2004a) state that, as far as the co-creation process is concerned, one of the suggested dimensions is dialogue because it is a natural communication channel to interact with the co-creators. Therefore, we consider that this conscience of communication of sorts doesn't enable the co-creation process; however, it can be fought by social media, thus, opening a "co-creative network" ( Donato, Farina, Donaire, \& Santos, 2017).

Taking into consideration that the co-creation and the gamification topics are relatively recent in the Portuguese business environment, some companies feel some constraints when they activated this type of methodology. All the respondents have presented factors which they believe to be critical for success (Q7), such as the commitment to strongly promote programs aiming at reaching the target audience, thus, allowing an increase in the return on investment (ROI). The feedback of the client must be taken into consideration from the very first moment in order to assure a more accurate focus and, in turn, lower the deviation risks while preventing possible budgetary slippages. The state is defined as a strategic partner, considering its support could mitigate part of the development's associated costs. In the case of company " $E$ ", the inclusion of material related to management in the secondary education system is also suggested, taking into account the fact that more 
than $50 \%$ of small and mid-size enterprise (SME)' managers in Portugal only have nine years of schooling (Medeiros, 2019).

In spite of the limited perception of value creation by brands within the scope of a co-creation system, it became clear the leverage that this process brings to the industry overpowered by the burgeoning presence of the marketing influencers. On the other hand, the measurement of the value created for companies is hardly an easy task, thus, entailing some liabilities. The process has been growing as far as transparency is concerned, but it is essential to put forward a set of control methods (KPIs and ROI) (Pilon \& Hadjielias, 2017; Zaborek \& Mazur, 2019).

Finally, we approach the topic related to the way companies would consider the feasibility of a co-created gamification methodology. As with any working methodology, there are risks and advantages in this type of tool, as far as hazards are concerned (Q8 and Q21). Companies have highlighted the so-called marketing myopia, conflict of interests and lack of trust, and the scarcity of resources as possible threats, in case the development process is not duly safeguarded. In the case of companies " $E$ " and "G", there is a special concern on the credibility damage that companies may suffer. They also pointed out the traditionalism associated with the business environment as a possible entry barrier and also the fact that this methodology could be seen by the client as an attempt to carry out the business verticalization, thus, leading to a failure in the intended impact; in this particular case, the existence of some conservative barriers in the implementation of a co-created gamification methodology is, in consequence, validated. Richard, Womack e Allaway (1993) identified the strategic frames of those companies, which are hostages of the business goals and SMART methodologies, disregarding the gamification's feedback power and the element stating that consumers want to play this game; being so, they should comply with the rules (Hogberg, Ramberg, Gustafsson, \& Wastlund, 2019; Raj, Gupta, \& Ieee, 2018).

On the other hand, companies are not unaware of the advantages inherent to the adoption of a co-created gamification methodology. In Q9 and Q22, some of the positive aspects of this type of strategy were pointed out. Special emphasis was given to the significant increase in the "engagement" of all the stakeholders, increase of external inputs, as well as the contribution to a market increment and product promotion, enabling a tool to create "custom services", as indicated by companies "E" and "F". At an internal level, these strategies also present some advantages, such as the fostering of teamwork productivity increment and alignment with the goals and promotion capacity regarding the informal relationship with all the intervenient parties. 
Breaking orthodoxies and being disruptive is rarely seen in the DNA of most of the small and conservative organizations found in the Portuguese business environment. In order to initiate scrutiny related to the interest of the respondents in adopting this methodology, we used Q18 to assess if they acknowledged that it could affect (or not) their reputation in the market and how. With the exception of company "A", the answers demonstrated that all the respondents recognized that the adoption of such a strategy has an effective impact on the company's reputation in the market. This impact may prove to be positive or negative, depending on the actions developed in the different stages of the process.

The results obtained are based on the idea that the implementation of a co-created gamification methodology strategy displays a tool that could provide a competitive advantage if used in the correct manner, thus, prevailing the risk of starting a disruptive process in the sector (Shams \& Kaufmann, 2016; Whalen \& Akaka, 2016).

As a way of validating the previously collected data, we used Q4 to confirm that all companies posit that the gain obtained through the adoption of a co-created gamification methodology totally justifies the cost associated with its development. This was confirmed by Q24, in which it was possible to conclude that five out of seven companies believe in the feasibility of this type of solution for the Portuguese market.

Although this is not a widely disclosed methodology in the Portuguese business environment, there are companies whose core business is the development of engagement solutions using gamification approaches. These companies operate in the business-to-business (B2B) market, and, in their projects' portfolio, they have partnerships with several sectors of activity, such as: automobile, cosmetics, distribution, human resources, insurance, health, industry, banking, construction, and food (Alsawaier, 2018; Nobre \& Ferreira, 2017; Silva, Verschoore, Bortolaso, \& Brambilla, 2019).

\section{CONCLUSION}

The present research aims to deepen the understanding of the relationship between co-creation and gamification qualitatively when applied to the services sector; to test the level of methodology acceptance in a peripheral country within a business sector mostly composed by SME operating in the services sector, and to contribute with insights to help companies to develop and implement strategies tailored to this type of markets. For this purpose, 
several interviews were carried out in national and international companies providing services and operating in the Portuguese market.

It was possible to conclude that all the respondents already knew the co-created gamification methodology, albeit they do not master it. It was also confirmed that, although it is a relatively recent topic, there are companies that are currently using this type of methodology and taking advantage of it. The company that profits most from this methodology is company "C". This company uses gamification metrics to evaluate the applicants and improve the levels of assertiveness of the employment allocations. Company "G" has also verified gains by working with this methodology; they used it to develop a service sharing program with its customers. The other companies presented daily practices of gamification tailored for engagement and team motivation, but they did not confirm the applicability of these advantages in the interactions with the stakeholders and the clients.

We observed that it is not necessary to look for extensive training to supply the companies with the essential valences that could allow them to develop this methodology, considering that they have confirmed the existence of a basic knowledge connected to it.

Regarding the sales resulting from the use of a co-created gamification methodology, it can be concluded that with the exception of company "G" (which beliefs in implementing this methodology to improve after-sales service), most companies perceived it as a tool to assure sales growth, leaving aside possible applications that don't lead to an immediate sale. After hearing the experience and knowledge of the respondents, it was possible to point out potential implementation strategies, such as the use of external trainers for companies without the necessary know-how, the creation of a network to produce and share knowledge with the several stakeholders, among others.

After comparing the advantages and the disadvantages related to the adoption of a co-created gamification methodology, we concluded that the majority of companies confirm the feasibility of its use; however, it should be developed under a controlled environment. Companies "A" and "E" showed a conservative attitude, which most certainly will hamper the implementation of a co-created gamification methodology.

Despite being the smallest and the most recently created companies, "F" and "G" bet on dematerialization of the business and, therefore, they tend to prefer to carry out their commercial activity indirect but digital contact, thus, looking for a structure reduction and suggesting a predisposition to counter the tendency inherent in companies of this kind in order to be more tolerant to risk. This research may be used by several companies, thus, 
allowing a more confident and disruptive approach towards their clients. It also enables a holistic view regarding the implicit motivations in the use of a co-created gamification methodology and the return expected by the organizations.

The results of this research may be considered beneficial for some economic agents in terms of knowledge and training for new methodologies. These new methodologies may even bring mid-term benefits to local economies. The use of innovative methodologies, such as co-creation, gamification, or the symbiosis of both, are already being put to practice by companies as a mechanism of engagement, motivation, and internal loyalty. As a consequence, the present research contributes to clarifying the implementation of these types of methodologies within the internal scope of the organizations.

This research provides input to the academic studies in the area of business sciences and strategies to deal with the creation of value. There are not many applied studies related to co-creation in the massive gaming market. This has been clearly a growing market due to the predominance of the new social trends. To help companies with the implementation of a co-created gamification methodology, it is crucial to assure cooperation with the clients in the creation of value.

Regarding the limitations of the present study, it should be mentioned that it contemplates only seven companies located in Portugal. Thus, it is impossible to generalize the results. Concerning the elaboration of the interviews, several questions included in previous studies were adapted and used. However, some relevant studies regarding this topic were not considered; consequently, some potentially interesting questions were left out.

As for future research lines, we suggest the elaboration of new research in companies belonging to other sectors. It is also necessary to carry out quantitative studies on the implementation of a co-created gamification methodology in companies in order to generalize the results. Another research could assess the impact of brand equity that results from gamification and co-creation through a study applied to consumers. It would also be possible to assess the impact of co-creation within the scope of gamification on a start-up's brand equity process and the liability/benefit factors in such a strategy at an early stage. 


\section{GAMIFICAÇÃO COMO UMA NOVA TENDÊNCIA NO PROCESSO DE COCRIAÇÃO}

) RESUMO

Objetivo: O uso de ferramentas digitais é uma realidade no cotidiano de grande parte da população mundial, seja no trabalho ou na vida social. A interação por meio do uso de mídias sociais, smartphones e jogos on-line está a crescer acentuadamente. Em relação aos jogos, estima-se que parte da população passa mais de 12 horas por semana em interações fornecidas por jogos on-line. Nesse contexto, o presente estudo tem como objetivo aprofundar a conexão entre a cocriação e a gamificação aplicadas ao setor de serviços.

Originalidade/valor: Este estudo procura contribuir para a redução do gap na literatura existente nas áreas da gamificação e cocriação quando aplicadas ao setor dos serviços. O facto de o estudo ser aplicado numa região periférica da Europa e com um tecido empresarial distinto contribui para um melhor entendimento sobre a relação estabelecida entre a cocriação gamificada e o tecido empresarial nesse tipo de regiões. Ajuda de igual modo as empresas no processo de implementação e desenvolvimento de novas estratégias.

Design/metodologia/abordagem: Utilizando uma metodologia qualitativa, foram realizadas sete entrevistas com diferentes empresas a atuar no setor dos serviços, localizadas em Portugal.

Resultados: Por meio deste estudo, será possível permitir uma melhor compreensão do mundo empresarial português e se esse ambiente corporativo está pronto e é recetivo a trabalhar com novas metodologias. Foi possível sinalizar algumas das boas práticas para a implementação de uma metodologia de cocriação gamificada, além de fornecer um alerta para os aspetos negativos que podem surgir ao trabalhar sob essa abordagem. As empresas reconhecem que a adoção de uma metodologia de cocriação gamificada traz algumas vantagens e aumenta seus níveis de competitividade no mercado.

\section{PALAVRAS-CHAVE}

Gamificação. Cocriação. Empresas. Marketing. Região periférica. 


\section{REFERENCES}

Aaker, D. A., \& Joachimsthaler, E. (1999). The lure of global branding. Harvard Business Review, 77(6), 137-144. Recuperado de https://www.ncbi. nlm.nih.gov/pubmed/10662002

Abdulahi, A., Samadi, B., \& Gharleghi, B. (2014). A study on the negative effects of social networking sites such as Facebook among Asia Pacific University scholars in Malaysia. International Journal of Business and Social Science, 5(10), 133-145.

Alexander, C. (2019). Using gamification strategies to cultivate and measure professional educator dispositions. International Journal of Game-Based Learning, 9(1), 15-29. doi:10.4018/ijgbl.2019010102

Alsawaier, R. S. (2018). The effect of gamification on motivation and engagement. International Journal of Information and Learning Technology, 35(1), 56-79. doi:10.1108/Ijilt-02-2017-0009

Bai, Y. (2018). How does co-creation affect customer's purchase intention? Journal of Industrial Integration and Management, 03(01), 1850005. doi:10.11 42/s2424862218500057

Barratt, M., Choi, T. Y., \& Li, M. (2011). Qualitative case studies in operations management: Trends, research outcomes, and future research implications. Journal of Operations Management, 29(4), 329-342. doi:10.1016/j. jom.2010.06.002

Bartle, R. (1996). Hearts, clubs, diamonds, spades: Players who suit MUDs. Journal of MUD Research, 1 (1), 1-19.

Buckley, P., Noonan, S., Geary, C., Mackessy, T., \& Nagle, E. (2019). An empirical study of gamification frameworks. Journal of Organizational and End User Computing, 31 (1), 22-38. doi:10.4018/Joeuc.2019010102

Camargo, A., Loureiro, O., \& Sodré, G. (2018). Se gosta de co-criar, gosta de ser empoderado? Co-criação dos clientes e suas preferências pelo empoderamento. Consumer Behavior Review, 2(1), 28-41.

Charitsis, V., Yngfalk, A. F., \& Skalen, P. (2019). "Made to run": Biopolitical marketing and the making of the self-quantified runner. Marketing Theory, 19(3), 347-366. doi:10.1177/1470593118799794

Deterding, S., Sicart, M., Nacke, L., O’Hara, K., \& Dixon, D. (2011). Gamification: Using game-design elements in non-gaming contexts. In CHI'11 extended abstracts on human factors in computing systems (pp. 2425-2428). doi:10.1145/1979742.1979575 
Donato, H. C., Farina, M. C., Donaire, D., \& Santos, I. C. D. (2017). Value co-creation and social network analysis on a network engagement platform. Revista de Administração Mackenzie, 18(5), 63-91. doi:10.1590/1678-697 12017/administracao.v18n5p63-91

Etgar, M. (2008). A descriptive model of the consumer co-production process. Journal of the Academy of Marketing Science, 36(1), 97-108. doi:10.1007/s11 747-007-0061-1

Fagerstrom, A., Bendheim, L. M., Sigurdsson, V., Foxall, G. R., \& Pawar, S. (2020). The marketing firm and co-creation: The case of co-creation by LEGO. Managerial and Decision Economics, 41(2), 226-233. doi:10.1002/ mde. 3077

Fernandes, A., \& Ussman, A. M. (2013). The learning ability of Portuguese small family businesses. International Journal of Entrepreneurship and Innovation Management, 17(1-3), 105-123. doi:10.1504/IJEIM.2013.055219

Fuchs, M. (2014). Gamification as twenty-first-century ideology. Journal of Gaming E Virtual Worlds, 6(2), 143-157. doi:10.1386/jgvw.6.2.143_1

Gatautis, R., Vitkauskaite, E., Gadeikiene, A., \& Piligrimiene, Z. (2016). Gamification as a mean of driving online consumer behaviour: SOR model perspective. Inzinerine Ekonomika-Engineering Economics, 27(1), 90-97. doi:10.5755/j01.ee.27.1.13198

Gomes, C. F. (2014). Comunidades online e cocriação: Estudo exploratório das motivações e barreiras à participação (Dissertação de mestrado). Instituto Superior de Economia e Gestão, Lisboa, Portugal.

Greenwood, F. (1992). Continuous improvements to meet customer expectations. Journal of Systems Management, 43(2), 13-15.

Hamari, J., Koivisto, J., \& Sarsa, H. (2014). Does gamification work? A literature review of empirical studies on gamification. Hawaii International Conference on System Sciences, Waikoloa, HI, USA, 47.

Harwood, T., \& Garry, T. (2015). An investigation into gamification as a customer engagement experience environment. Journal of Services Marketing, 29(6-7), 533-546. doi:10.1108/jsm-01-2015-0045

Heavey, C., Ledwith, A., \& Murphy, E. (2014). Introducing a new continuous improvement framework for increased organisational return on investment. The TQM Journal, 26(6), 594-609. doi:10.1108/tqm-06-2013-0065

Hogberg, J., Ramberg, M. O., Gustafsson, A., \& Wastlund, E. (2019). Creating brand engagement through in-store gamified customer experiences. Journal 
of Retailing and Consumer Services, 50, 122-130. doi:10.1016/j.jretconser. 2019.05.006

Ind, N., \& Coates, N. (2013). The meanings of co-creation. European Business Review, 25(1), 86-95. doi:10.1108/09555341311287754

Kambil, A., Friesen, G. B., \& Sundaram, A. (1999). Co-creation: A new source of value. Outlook Magazine, 3(2), 23-29.

Kim, T. W. (2018). Gamification of labor and the charge of exploitation. Journal of Business Ethics, 152(1), 27-39. doi:10.1007/s10551-016-3304-6

Kohler, T., Fueller, J., Matzler, K., \& Stieger, D. (2011). Co-creation in virtual worlds: The design of the user experience. MIS Quarterly, 35(3), 773-788. doi: $10.2307 / 23042808$

Kotler, P., Kartajaya, H., \& Setiawan, I. (2016). Marketing 4.0: Moving from traditional to digital. Hoboken, NJ: John Wiley \& Sons.

Kuula, S., Haapasalo, H., \& Tolonen, A. (2018). Cost-efficient co-creation of knowledge intensive business services. Service Business, 12 (4), 779-808. doi:10.1007/s11628-018-0380-y

Landers, R. N. (2019). Gamification misunderstood: How badly executed and rhetorical gamification obscures its transformative potential. Journal of Management Inquiry, 28(2), 137-140. doi:10.1177/1056492618790913

Lopes, J., Farinha, L., Ferreira, J., \& Ferreira, F. (2018). Peeking beyond the wall: Analysing university technology transfer and commercialisation processes. International Journal of Technology Management, 78(1-2), 107-132. doi:10.1504/ijtm.2018.093936

López-Herrera, F., \& Salas-Harms, H. (2009). Qualitative research in business studies. Cinta de Moebio, (35), 128-145. doi:10.4067/s0717-554×2009000 200004

Lucas, S. R. (2014). Beyond the existence proof: Ontological conditions, epistemological implications, and in-depth interview research. Quality $\mathcal{E}$ Quantity, 48(1), 387-408. doi:10.1007/s11135-012-9775-3

Marczewski, A. (2018). Even Ninja monkeys like to play: Unicorn Edition. Independently published.

Martinez-Canas, R., Ruiz-Palomino, P., Linuesa-Langreo, J., \& Blazquez-Resino, J. J. (2016). Consumer participation in co-creation: An enlightening model of causes and effects based on ethical values and transcendent motives. Frontiers in Psychology, 7, 776-793. doi:10.3389/fpsyg.2016.00793 
Martovoy, A., \& Santos, J. D. (2012). Co-creation and co-profiting in financial services. International Journal of Entrepreneurship and Innovation Management, 16(1-2), 114-135.

Medeiros, J. (2019). Metade das empresas mais pequenas têm um gestor com o $9^{\circ}$ ano ou menos. Jornal Económico. Recuperado de https://jornal economico.sapo.pt/noticias/metade-das-empresas-mais-pequenas-temum-gestor-com-o-9o-ano-ou-menos-501345

Minikel-Lacocque, J. (2019). The affect-responsive interview and in-depth interviewing: What we can learn from therapy research. Qualitative Inquiry, 25(9-10), 1039-1046. doi:10.1177/1077800418792941

Nobre, H., \& Ferreira, A. (2017). Gamification as a platform for brand co-creation experiences. Journal of Brand Management, 24(4), 349-361. doi:10.1057/s41262-017-0055-3

Nogueira-Pellizzoni, L., \& Baldanza, R. F. (2019). Co-creation in conventional and collaborative businesses. Estudios Gerenciales, 35(151), 95-108. doi:10.18046/j.estger.2019.151.3055

Oertzen, A.-S., Odekerken-Schröder, G., \& Mager, B. (2020). Driving users' behaviours and engagement in co-creating services. Journal of Services Marketing, 34(4), 549-573. doi:10.1108/JSM-06-2019-0244

Omar, N. A., Kassim, A. S., Shah, N. U., Alam, S. S., \& Wel, C. A. C. (2020). The influence of customer value co-creation behavior on SME brand equity: An empirical analysis. Iranian Journal of Management Studies, 13 (2), 165-196. doi:10.22059/ijms.2019.280005.673611

Patricio, R., Moreira, A., Zurlo, F., \& Melazzini, M. (2020). Co-creation of new solutions through gamification: A collaborative innovation practice. Creativity and Innovation Management, 29(1), 146-160. doi:10.1111/caim. 12356

Payne, A. F., Storbacka, K., \& Frow, P. (2008). Managing the co-creation of value. Journal of the Academy of Marketing Science, 36(1), 83-96. doi:10.1007/ s11747-007-0070-0

Pestana, G. C. F. (2019). Gamifying the product quality reviews in the pharmaceutical industry. European Conference on Knowledge Management, Lisbon, Portugal, 20.

Pilon, F., \& Hadjielias, E. (2017). Strategic account management as a value co-creation selling model in the pharmaceutical industry. Journal of Business $\mathcal{E}$ Industrial Marketing, 32(2), 310-325. doi:10.1108/Jbim-05-2015-0100 
Pink, D. H. (2011). Drive: The surprising truth about what motivates us. London: Penguin.

Portuguese Family Business Association (2020). Empresas familiares em Portugal. Recuperado de https://empresasfamiliares.pt/

Prahalad, C., \& Ramaswamy, V. (2001). The value creation dilemma: New building blocks for co-creating experience. Harvard Business Review, 18(3), 5-14.

Prahalad, C. K., \& Ramaswamy, V. (2004a). Co-creation experiences: The next practice in value creation. Journal of Interactive Marketing, 18(3), 5-14. doi:10.1002/dir.20015

Prahalad, C. K., \& Ramaswamy, V. (2004b). The future of competition: Co-creating unique value with customers. Brighton, MA: Harvard Business Press.

Raj, B., Gupta, D., \& Ieee (2018). Factors influencing consumer responses to marketing gamification. Ieee.

Ramaswamy, V., \& Gouillart, F. (2010). Building the co-creative enterprise. Harvard Business Review, 88(10), 100-109.

Richard, M. D., Womack, J. A., \& Allaway, A. W. (1993). Marketing myopia: An integrated view. Journal of Product \& Brand Management, 2(3), 49-54. doi:10.1108/eum0000000002979

Ryan, R. M., \& Deci, E. L. (2000). Intrinsic and extrinsic motivations: Classic definitions and new directions. Contemporary Educatinal Psychology, 25(1), 54-67. doi:10.1006/ceps.1999.1020

Salcu, A. V., \& Acatrinei, C. (2013). Gamification applied in affiliate marketing. Case study of 2Parale. Management \& Marketing, 8(4), 767-790.

Sanders, E. B.-N., Brandt, E., \& Binder, T. (2010). A framework for organizing the tools and techniques of participatory design. Proceedings of the Biennial Participatory Design Conference, Sydney, Australia, 11. doi:10.1145/1900441. 1900476

Scharp, K. M., \& Sanders, M. L. (2019). What is a theme? Teaching thematic analysis in qualitative communication research methods. Communication Teacher, 33(2), 117-121. doi:10.1080/17404622.2018.1536794

Shams, S. M. R., \& Kaufmann, H. R. (2016). Entrepreneurial co-creation: A research vision to be materialised. Management Decision, 54(6), 1250-1268. doi:10.1108/Md-11-2015-0487

Siguaw, J. A., Gassenheimer, J. B., \& Hunter, G. L. (2014). Consumer cocreation and the impact on intermediaries. International Journal of Physical 
Distribution \& Logistics Management, 44(1-2), 6-22. doi:10.1108/Ijpdlm01-2012-0019

Silva, L. F. S., Verschoore, J. R., Bortolaso, I. V., \& Brambilla, F. R. (2019). The effectiveness of game dynamics in cooperation networks. European Business Review, 31 (6), 870-884. doi:10.1108/ebr-06-2018-0118

Singh, S., \& Sonnenburg, S. (2012). Brand performances in social media. Journal of Interactive Marketing, 26(4), 189-197. doi:10.1016/j.intmar.2012. 04.001

Šlibar, B., Vukovac, D. P., Lovrenčić, S., Šestak, M., \& Andročec, D. (2018). Gamification in a business context: Theoretical background. Central European Conference on Information and Intelligent Systems, Zagreb, Croatia, 29.

Taghizadeh, S. K., Jayaraman, K., Ismail, I., \& Rahman, S. A. (2016). Scale development and validation for DART model of value co-creation process on innovation strategy. Journal of Business \& Industrial Marketing, 31(1), 24-35. doi:10.1108/jbim-02-2014-0033

Tekic, A., \& Willoughby, K. W. (2017). Contextualised co-creation: Innovating with individual external contributors throughout the product life cycle. International Journal of Product Development, 22 (3), 230-245. doi:10.1504/ ijpd.2017.087380

Vedrashko, I. (2011). Game-based marketing: Inspire customer loyalty through rewards, challenges, and contests. International Journal of Advertising, 30(1), 189-190. doi:10.2501/Ija-30-1-189-190

Ward, E., Yang, S., Romaniuk, J., \& Beal, V. (2020). Building a unique brand identity: Measuring the relative ownership potential of brand identity element types. Journal of Brand Management, 27(4), 393-407. doi:10.1057/ s41262-020-00187-6

Werbach, K. (2014). (Re)defining gamification: A process approach. In A. Spagnolli, L. Chittaro, L. Gamberini (Eds.). Persuasive Technology: Persuasive 2014: Lecture notes in Computer Science. Cham: Springer. doi:10.1007/978-3-319-07127-5_23

Whalen, P. S., \& Akaka, M. A. (2016). A dynamic market conceptualization for entrepreneurial marketing: The co-creation of opportunities. Journal of Strategic Marketing, 24(1), 61-75. doi:10.1080/0965254x.2015.1035040

Witell, L., Kristensson, P., Gustafsson, A., \& Löfgren, M. (2011). Idea generation: Customer co-creation versus traditional market research techniques. Journal of Service Management, 22(2), 140-159. doi:10.1108/095642311 11124190 
Woz'niak, J. (2017). Some factors hindering acceptance of three gamification solutions in motivation systems, in small and medium enterprises. Management Dynamics in the Knowledge Economy, 5(4), 663-680. doi:10.25019/ mdke/5.4.11

Yin, R. K. (2015). Qualitative research from start to finish. New York: Guilford. Yust, K.-M. (2014). Digital power: Exploring the effects of social media on children's spirituality. International Journal of Children's Spirituality, 19(2), 133-143. doi:10.1080/1364436x.2014.924908

Zaborek, P., \& Mazur, J. (2019). Enabling value co-creation with consumers as a driver of business performance: A dual perspective of Polish manufacturing and service SMEs. Journal of Business Research, 104, 541-551. doi:10. 1016/j.jbusres.2018.12.067

Zichermann, G., \& Linder, J. (2010). Game-based marketing: Inspire customer loyalty through rewards, challenges, and contests. Hoboken, NJ: John Wiley \& Sons.

Zielinski, D. (2015). The gamification of recruitment. HRMagazine, 60(9), 59-61.

Zwass, V. (2010). Co-creation: Toward a taxonomy and an integrated research perspective. International Journal of Electronic Commerce, 15(1), 11-48. doi:10.2753/Jec1086-4415150101

\section{AUTHOR NOTES}

Ivo M. F. M. Rodrigues, graduated from the Higher Institute of Accounting and Administration do Porto, Polytechnic Institute; Nuno F. M. Soares, graduated from the Department of Management, European Business School (Higher Institute of Administration and Management - Isag); João M. Lopes, Ph.D. from the Department of Management and Economics, University of Beira Interior (UBI); José C. Oliveira, Ph.D. from the Department of Management and Economics, University of Minho (Uminho); Jorge M. N. G. Lopes, Ph.D. from the Department of Management and Economics, Rey Juan Carlos University (URJC).

Ivo M. F. M. Rodrigues is now a master student at the Department of Management of European Business School (Isag); Nuno F. M. Soares is now a master student at the Department of Management of European Business School (Isag); João M. Lopes is now an assistant professor at the Department of Management and Economics of Miguel Torga Higher Institute and of Research Unit for Business Sciences (Nucleus of Studies in Business Sciences - Nece) of UBI; José C. Oliveira is now an assistant professor at the Department of Management and Economics of Uminho; Jorge M. N. G. Lopes is now an adjunct professor at the Department of Management and of Research Nucleus of European Business School (Nidisag).

Correspondence concerning this article should be addressed to João. M. Lopes, Largo Cruz de Celas, no 1, Santo Antônio dos Olivais, Coimbra, Portugal, Postal Code 3000-132.

E-mail: joao.lopes.1987@hotmail.com 


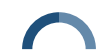

Gamification as a new trend in the co-creation process

EDITORIAL BOARD

Editor-in-chief

Gilberto Perez

Associate editor

Francisco Américo Cassano

Technical support

Vitória Batista Santos Silva

\section{EDITORIAL PRODUCTION}

Publishing coordination

Jéssica Dametta

Language editor

Daniel de Almeida Leão

Layout designer

Emap

Graphic designer

Libro 